\title{
Water-saving techniques for restoring desertified lands: Some lessons from the field
}

\author{
Vicenç Carabassa ${ }^{1,2}$ ( ) | Daniela Alba-Patiño ${ }^{3}$ | Sergio García ${ }^{1}$ | Julián Campo ${ }^{4}$ | \\ Harrie Lovenstein $^{5}$ | Gertruud Van Leijen ${ }^{6}$ | Antonio J. Castro ${ }^{3,7}$ | \\ Francisco González $^{8}$ | Gustavo Viera ${ }^{9}$ | Dimitrios-Sotirios Kourkoumpas ${ }^{10}$ | \\ Argyro Aliki Zioga $^{10}$ | Christos Emmanouel Papadelis ${ }^{10}$ | Vicente Andreu ${ }^{4}$ | \\ Eugènia Gimeno $^{4}$ | Sven Kallen ${ }^{11}$ | Josep Maria Alcañiz ${ }^{1,2}$
}

${ }^{1}$ CREAF, Univ Autònoma de Barcelona, Cerdanyola del Vallès, Spain

${ }^{2}$ Universitat Autònoma de Barcelona, Cerdanyola del Vallès, Spain

${ }^{3}$ Department of Biology and Geology, Andalusian Center for the Assessment and Monitoring of Global Change (CAESCG),

Universidad de Almería, Almería, Spain

${ }^{4}$ Centro de Investigaciones sobre Desertificación (CIDE-CSIC), Valencia, Spain

${ }^{5}$ Land Life Company, Amsterdam, The Netherlands

${ }^{6}$ Van Leijen Srl, Rome, Italy

${ }^{7}$ Department of Biological Sciences, Idaho State University, Pocatello, Idaho, USA

${ }^{8}$ Consejería de Medio Ambiente, Cabildo de Gran Canaria, Las Palmas de Gran Canaria,

Spain

${ }^{9}$ Gestión y Planeamiento Territorial y Medioambiental, Gobierno de Canarias, Las Palmas de Gran Canaria, Spain

${ }^{10}$ Centre for Research and Technology Hellas/ Chemical Process and Energy Resources Institute (CERTH/CPERI), 4th km Ptolemaida Mpodosakio Hospital, Athens, Greece

${ }^{11}$ VOLTERRA ECOSYSTEMS, Bellaterra, Spain

\section{Correspondence}

Vicenç Carabassa CREAF, Soil Protection and Restoration Group, Edifici C, Universitat Autònoma de Barcelona, E08193 Bellaterra (Cerdanyola del Vallès), Catalonia, Spain. Email:v.carabassa@creaf.uab.cat

Funding information

EU Life Program, Grant/Award Numbers:

LIFE15 CCA/ES/000125, LIFE19

CCM/ES/001199

\begin{abstract}
Nature-based solutions can significantly contribute to restoration projects in areas affected by desertification processes, where they are necessary for reversing land degradation. Currently, one innovative solution is The Cocoon $^{\text {TM }}$, which has been designed as a new ecotechnology for improving seedling establishment. The Cocoon consists of a doughnut-shaped container made of recycled cardboard that provides water and shelter at least during the first year of a seedling, which is the most critical for plant establishment. To determine the effectiveness of this ecotechnology under different conditions, the Cocoon was tested on a variety of soils, climates, vegetation, and land uses. Six planting trials were performed in Spain and Greece, which covered a range from humid to arid climates. With the objective of studying its functionality, the survival of the seedlings, their vigor, and growth were monitored for 2 years. Compared with conventional planting systems, the Cocoon has effectively increased seedling survival, especially under dry growing conditions (low rainfall, soils with low water holding capacity). The Cocoon also allowed for higher growth of some species (olive trees, holm oaks, and Aleppo pines). Moreover, a positive correlation between the rainfall on the site and the biodegradation degree of the Cocoon device was observed. Overall, the Cocoon becomes more efficient in arid climates or adverse growing conditions.
\end{abstract}

\section{KEYWORDS}

climate change adaptation, Cocoon, drylands, irrigation, planting 


\section{1 | INTRODUCTION}

One of the most current ecological concerns is the increasing desertification rate as a direct impact of the climate crisis. According to the United Nations Convention to Combat Desertification, areas with the highest susceptibility to desertification are dry, arid, semiarid and subhumid areas (MAP, 2019), such as large parts of the Mediterranean region. These 'drylands' occupy $41 \%$ of the Planet's land surface and are inhabited by ca 2 billion people (MEA, 2005). A common trait of these areas is that the aridity index ranges between 0.05 and 0.65 (MAPA, 2019).

Desertification, particularly its consequent reduction of ecosystem services, can threaten future improvements in human wellbeing and impede progressive efforts in dryland areas affected by climatic impacts, such as control measures for dust storms or floods. Desertification reduces primary production and microbial activity, modifies the nutrient cycles, and increases soil degradation, which altogether result in the inability to capture carbon and the loss of biodiversity of affected ecosystems (MEA, 2005). The consequences of desertification can also be their causes, thus embodying a detrimental cycle. Therefore, combating desertification becomes one of the great global environmental challenges, and its effects must also be considered globally.

However, at the local level, desertification may depend on the combination of multiple factors and site-specific processes that may aggravate the problem. These include indirect factors, such as population size pressure, political and socioeconomic scenarios, on the one hand, and direct factors, such as land use and management as well as climate-related processes, on the other. The main aggravating factors at the local level include seasonal droughts with extreme rainfall variability and/or heavy rains, poor soils prone to erosion, steeped slopes that increase the energy of runoff, recurrent forest fires causing loss of vegetation cover and changes in the physical, chemical, and biological soil properties (Campo et al., 2006, 2008), crisis of traditional agriculture resulting in land abandonment, unsustainable exploitation and salinization of aquifers, bad agricultural and livestock practices, and overpopulation in some areas (MAP, 2019).

All these factors cause direct impact and stress on vegetation and its growth. Most of these conditions occur or have occurred throughout the Mediterranean basin. Specifically, more than two-thirds of the Spanish territories are classified as arid, semiarid, and dry subhumid areas, and more than two-thirds of these territories present a risk of desertification to a greater or lesser degree (MAP, 2019; WWF, 2016). The capacity of ecosystems to regenerate is limited in those areas, and therefore restoring degraded land is becoming essential for restoring the integrity of impacted forests, rangelands, mineaffected areas, and numerous habitats that host valuable biodiversity (Muñoz-Rojas et al., 2021).

At present, despite the efforts made, reforestation in the Mediterranean region cannot be considered satisfactory in many cases due to the slow growth of planted seedlings and extremely high mortality rates (Valdecantos et al., 2014). Planting sites suffer water stress due to droughts that last between 3 and 5 months. They can also experience nutrient limitations when the seedlings are transferred to the soil, which is typically poor in the Mediterranean region (DíazHernández et al., 2003). Water stress increases in mine soils because of their shallow depth and lack of soil structure. Thus, they have very low water holding capacity (López-Marcos et al., 2020), which limit plant establishment even in Mediterranean subhumid climate (Alday et al., 2016). Even if reforestation is carried out with regular irrigation, the survival rate is at most $50 \%$ for many species, but in many cases even less, since root systems with inadequate irrigation do not penetrate deep enough into the soil and remain in the surface layers (Salem, 1989).

In this context, nature-based solutions could help solve environmental problems and improve reforestation projects by increasing seedling establishment. Nature-based solutions are defined as actions that protect, sustainably manage, and restore natural or modified ecosystems addressing societal challenges effectively and adaptively, while simultaneously providing human well-being and biodiversity benefits. Nature-based solutions are usually regarded as an umbrella concept that covers a range of different approaches (Cohen-Shacham et al., 2016). Therefore, ecotechnologies designed for supporting restoration projects and plantings could also be included in this group of solutions.

The Cocoon ${ }^{\mathrm{TM}}$, a new water-saving ecotechnology for supporting plantings in drylands, is currently used abroad (Land Life Company, 2021). The Cocoon resembles the buried clay pot used in ancient times, in which water slowly seeps into the subsurface to support plant growth and restricts evaporation losses, as would be expected during conventional watering of the soil surface. Instead of fragile and bulky pots, a paper pulp-based alternative was devised to support early tree establishment in reforestation schemes under dryland conditions. With preliminary tests of an early version of the Cocoon as proof of principle, larger field tests have been laid out since 2016 in the Mediterranean basin and Canary Islands (VOLTERRA, 2021) and in the Lower Rio Grande Valley of South Texas (Mohsin et al., 2021), among others.

The objective of this work is to analyze the results of the largescale implementation of the Cocoon solution by means of the data collected in different field trials carried out in restoration projects. The main parameters evaluated have been seedling survival, vigour, and growth to verify the effectiveness of this technology in the wide range of land uses and environmental conditions present in six study areas located in the Mediterranean region and the Canary Islands.

\section{2 | MATERIAL AND METHODS}

\subsection{The Cocoon device}

The Cocoon $^{\mathrm{TM}}$ consists of a doughnut-shaped container (like a torus geometrical figure) made of recycled cardboard. This device has a capacity for 25 litres of water and a central space to install the seedling. It is designed to provide water and shelter to the seedling, at least during its first year, which is usually its most critical survival stage. A 
lid reduces evaporation losses from the bowl and a shelter protects the seedling against small herbivores and reduces evapotranspiration. For the Cocoon installation, the soil must be prepared beforehand by first digging a hole of $20 \mathrm{~cm}$ depth and $50 \mathrm{~cm}$ diameter, where this device can be introduced (Figure 1). Over time it biodegrades and integrates itself into the ground.

\subsection{Study areas}

The Cocoon system was used in six restoration areas located in Spain and Greece (see Table S1). In Spain, five large demonstration areas were located in El Bruc (Catalonia), Jijona and Tous (Valencia), Sierra de María (Almería), and Tifaracás (Canary Islands); and in Greece, one area in Ptolemais (Western Macedonia). These areas cover a variety of soils, Mediterranean mesoclimates (from humid to arid), vegetation and land use, where the effectiveness of the Cocoon device can be tested in different conditions on several desertification scenarios, and in combination with different nature-based solutions for forest fire vulnerability reduction, endangered/endemic species protection, open-pit mines restoration or recuperation of agricultural land (CREAF, 2017a).

For our case-studies, we focused on burned forest soils with relatively high organic matter content in El Bruc and Tous and poor soils with low organic matter content in Jijona (abandoned cropland) and Tifaracás (volcanic parent material). In Ptolemais, the soil derives from the mining debris of a former coal mine, where the planting was carried out. The soil in this particular location presents very high contents of carbonates and coal particles. Table 1 presents the main characteristics of the studied areas, and Table 2 presents the respective soils.

\section{3 | Planting}

The planting scheme was based on the combination of one set of seedlings planted directly in the soil (controls), which represent the traditional way, and another set planted with the Cocoon. Each control was surrounded by several associated Cocoons, depending on the planting possibilities of the site. As a rule, a 1:3 control:Cocoon ratio was used. Thus, each control provides paired measures with its associated Cocoon, whereby an encoding system was set that allowed data coupling.

In total, 22,301 seedlings of 31 different species or varieties were planted on an entire surface of 73 ha (see Table S1), according to restoration objectives, environmental conditions and climate change scenarios. Planting was carried out in two phases: the first phase in Autumn 2016, and the second in Spring-Summer 2017. Cocoon installation was carried out using a $50 \mathrm{~cm}$ diameter drill installed in a tractor or a backhoe whenever topographic and soil conditions made it possible. In steeped slopes and extremely stony soils, holes were made manually (see Table S1). Once planted, the Cocoons were filled with $25 \mathrm{~L}$ of spring water, in addition to natural rain, while the controls were watered with a similar amount of water, but no refilling/ irrigation was performed thereafter, with the exception of third and fourth plantings in Tifaracás, where the Cocoons were refilled.

\section{4 | Monitoring parameters}

Monitoring parameters were divided into two groups: (i) one for evaluating the Cocoon effects on plant vigour and growth, vegetation exclusion, and Cocoon biodegradation; and ii) the other for evaluating the recovery by means of passive restoration of the plantation areas.

Plant vigor was evaluated according to the following semiquantitative scores during their normal growing period:

3: Healthy seedling, with more than $75 \%$ of green, no wilted leaves, with active growing points (apices) visible

2: Affected seedling, with $25 \%-75 \%$ of the leaves being wilted, yellow, or brown

1: Severely affected seedling with less than $25 \%$ of the leaves being green (i.e. the majority wilted, yellow or brown)

0 : Presumably dead seedling with no leaves or only wilted leaves; however, seedlings may still recover by resprouting after rain occurs

R: Resprouted seedling

With the use of a caliper, plant growth was assessed by measuring maximum plant height, from the root crown to the shoot apex, and the
FIGURE 1 Cocoon scheme and The Cocoon is filled with 25 liters of water and buried subsurface with the seedling

functioning [Colour figure can be viewed at wileyonlinelibrary.com]

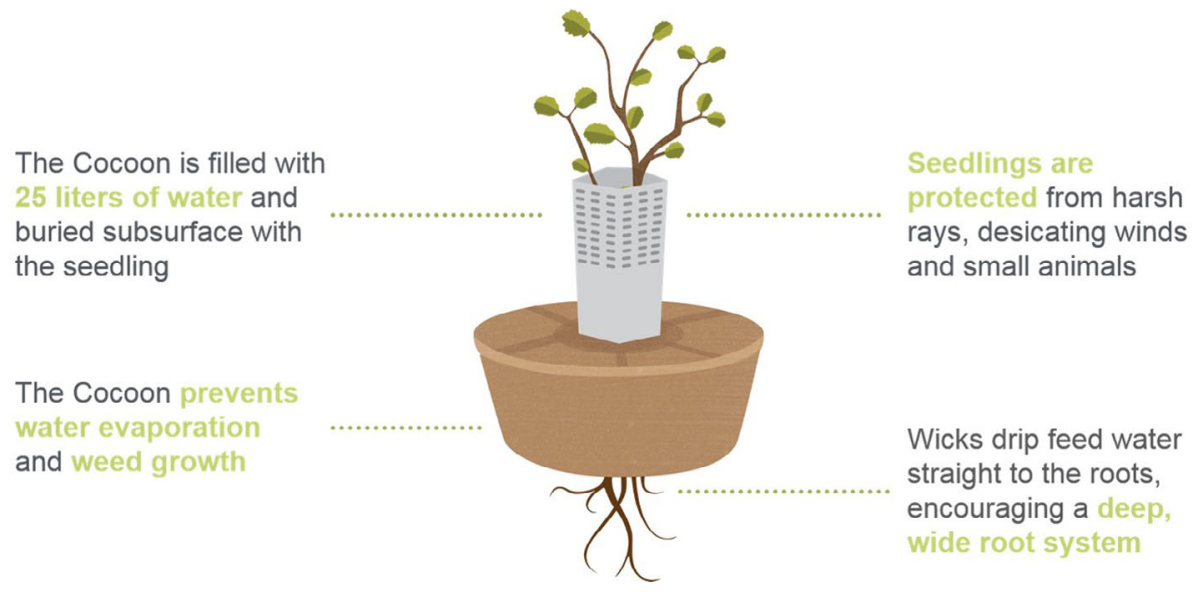

Wicks drip feed water to the roots, encouraging a deep,
wide root system 


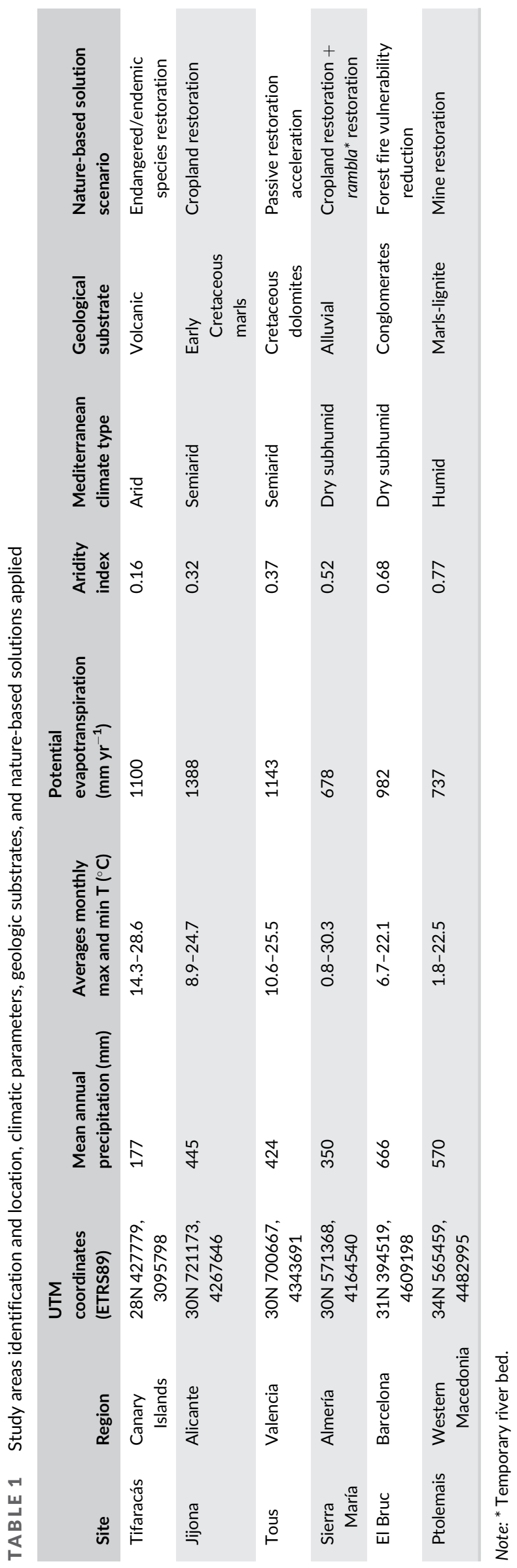

stem diameter at the tree base (at the level of the Cocoon's lid, at $10 \mathrm{~cm}$ of soil). Vegetation exclusion was evaluated in $1 \mathrm{~m}$ diameter circle around the seedling, measuring vegetation cover in two perpendicular transects. Additionally, biomass was evaluated by harvesting and weighing all the vegetation inside the circle (wet weight: weight at field; dry weight: weight after drying at $60^{\circ} \mathrm{C}$ for 4 days). Cocoon biodegradation was evaluated by ranging each Cocoon from States 1 to 4,1 being the intact device, and 2, 3, and 4 being increased biodegradation until complete incorporation into the soil. State 2 corresponded to a Cocoon without lid or a partially collapsed one.

Passive restoration was measured by means of vegetation structure measures and floristic inventories. Structure was evaluated by quantifying cover types and height, each having $20 \mathrm{~cm}$ in $25 \mathrm{~m}$ transects, a minimum of 3 transects per ha, which are parallel and perpendicular to the slopes (see the area of each study site in Table S1). Transect vertex was fixed with metal bars in order to repeat measurement at the same place. For this, each vertex was identified with UTM coordinates or a specific code (Carabassa et al, 2019).

Floristic inventories were made identifying all plant species in each area, which distinguished each site or subsite (according to sitespecific variability). Additionally, an abundance estimation per species was performed using these pattern rankings:

\section{1: $0 \%-5 \%$ soil cover \\ 2: low frequency ( $<25 \%$ soil cover)}

3: high frequency ( $25 \%-75 \%$ soil cover)4: dominant ( $>75 \%$ soil cover)

A protocol for measuring all these parameters was specifically defined (CREAF, 2017b). Data were obtained in two field campaigns carried out in all plantations: one before Summer 2017 and another one after 2 years, in late Spring 2019. For the third and fourth plantings in Tifaracás, further monitoring was carried-out in 2020, whereby only seedlings survival was measured (Table S1).

\section{5 | Statistical analysis}

Seedling survival and physiological state, Cocoon degradation, plant height, stem diameter, root development, and microsite biomass and cover (vegetation exclusion) were analyzed using R Studio. The normal probability test and the Breusch-Pagan test were used to check normality and homoscedasticity. Analyses of the differences between treatments (control and Cocoon) were performed using the MannWhitney test, since only two treatments were tested. Analyses on the study sites were performed using the Kruskal-Wallis test, since more than two treatments were tested. To determine significant differences, a value of $\alpha=0.05$ was applied.

\section{3 | RESULTS}

\section{1 | Seedling survival and physiological state}

Analyzing the survival values together for all the study areas, plant species and contrasted differences could be observed. Seedlings that 
TABLE 2 Main soil characteristics of the study areas

\begin{tabular}{|c|c|c|c|c|c|c|c|c|}
\hline Site & Texture & $\mathrm{CaCO}_{3}(\%)$ & $\begin{array}{l}\text { CEC } \\
\left(\mathrm{cmol} \mathrm{kg}^{-1}\right)\end{array}$ & $\begin{array}{l}\mathrm{pH} \text { water } \\
(1: 2,5 \mathrm{w} / \mathrm{v})\end{array}$ & $\mathrm{EC}\left(\mathrm{dS} \mathrm{m^{-1 } )}\right.$ & SOM (\%) & $\begin{array}{l}\text { SOC stock } \\
\left(\mathrm{T} \mathrm{ha}^{-1}\right)\end{array}$ & Comments \\
\hline Tifaracás & Clay & $6.5 \pm 3.0^{a}$ & $43.7 \pm 3.4^{c}$ & $7.70 \pm 0.23^{a}$ & $0.95 \pm 0.13^{\mathrm{ab}}$ & $1.62 \pm 0.35^{\mathrm{a}}$ & $12.99 \pm 3.81^{\mathrm{a}}$ & Steep slope, stony \\
\hline Tous & Clay & $9.4 \pm 13.9^{\mathrm{a}}$ & $28.1 \pm 5.4^{b}$ & $7.49 \pm 0.28^{a}$ & $0.46 \pm 0.11^{a}$ & $3.39 \pm 1.30^{\mathrm{a}}$ & $26.69 \pm 9.59^{\mathrm{ab}}$ & Shallow and stony \\
\hline $\begin{array}{l}\text { Sierra } \\
\text { María }\end{array}$ & Clay loam & $58.1 \pm 5.7^{c}$ & $20.8 \pm 4.5^{\mathrm{ab}}$ & $7.72 \pm 0.04^{a}$ & $0.78 \pm 0.27^{\mathrm{ab}}$ & $3.18 \pm 1.30^{\mathrm{a}}$ & $38.09 \pm 7.23^{b}$ & $\begin{array}{l}\text { Tilled, petrocalcic } \\
\text { horizon }\end{array}$ \\
\hline Ptolemais & Sandy & $67.2 \pm 14.6^{\mathrm{cd}}$ & $24.4 \pm 13.6^{\mathrm{ab}}$ & $7.66 \pm 0.20^{a}$ & $1.51 \pm 1.08^{b}$ & $7.47 \pm 14.39^{a}$ & $29.19 \pm 14.02^{b}$ & Mining debris, stony \\
\hline
\end{tabular}

Note: Values represent mean \pm standard deviation. Different letters indicate significant differences at $p<0.05$ between study areas for each variable. Abbreviations: $\mathrm{CaCO}_{3}$, Calcium carbonate content; $\mathrm{CEC}$, cation exchange capacity; EC, electric conductivity; SOC stock, Soil organic carbon stock; SOM, Soil organic matter

planted with the Cocoon methodology showed greater survival, with a rate close to $60 \%$, while the control ones showed lower rates of up to $40 \%(p<0.0001)$. Regarding the vigor of the survivors, the seedlings with good health predominated in both cases (control and Cocoon treatments), but with a higher percentage in the Cocoon treatment, in which only few plants were severely affected or resprouted. However, some particular tendencies can be observed when data are analyzed for each planting area (Figure 2).

In the El Bruc, Jijona, and Tous planting sites, differences between controls and Cocoons were observed in terms of mortality and the number of healthy plants (see Figures S2-S5). In contrast, in Sierra María, there were no differences in seedling mortality between the control and Cocoon treatments, which both yielded $37 \%$ survival rates. In addition, control seedlings showed greater vigor, with a greater number of healthy seedlings (36\%), compared with those with Cocoon (26\%). Survival in Ptolemais' planting sites was high on both treatments. The percentage of affected seedlings was very low, and only appeared in the Cocoon treatment. In contrast, survival in Tifaracás was low in both treatments, even though the seedlings planted with Cocoon presented a higher percentage of healthy seedlings (21\%), compared with controls (12\%).

However, vigor results are not only dependent on location but also on plant species, for example, Rosmarinus officinalis L. (rosemary) and Prunus dulcis (Mill.). D. A. Webb (almond tree) in Sierra María showed high survival ratios in Cocoons like respective controls, while Tamarix gallica L. (French tamarisk) presented high mortality ratios in both treatments, with mortality being much higher in the controls, which reached a $100 \%$ mortality ratio (see Figure S1). In Ptolemais, the highest mortality basically affected Cupressus sempervirens L. (cypress) specimens (see Figure S2).

The overall results in Tifaracás were largely determined by local harsh conditions, especially the drought in Summer 2017, which occurred just after planting. Despite this, seedlings planted in the Cocoon had better physiological state than controls. Pistacia atlantica Desf. (mastic tree) had high mortality rates in both treatments, but survival was higher in Cocoons, albeit with a high percentage of severely affected seedlings. Mortality was also high in Juniperus turbinata ssp. canariensis Guyot (Canarian juniper), being 100\% in controls and close to $80 \%$ in Cocoons. The best survival results were obtained with Olea europaea L. ssp. guanchica (Canarian wild olive), having a mortality rate that did not reach $25 \%$ of the specimens and a relatively high percentage of healthy seedlings, which was close to $50 \%$. In respective controls, mortality and affected seedling rates were higher (32\% and $38 \%$, respectively).

All the species planted in El Bruc and Jijona showed a similar trend, whereby a better physiological state in the Cocoon treatment could be observed. However, for some of them, such as Ceratonia siliqua L. (carob tree), Olea europaea L. var. europaea (vera olive tree), Prunus avium L. (cherry tree), and Prunus spinosa L. (blackthorn), the mortality of controls exceeded $80 \%$. In El Bruc, the best results were obtained for the two subspecies of Quercus ilex L. (subsp. ilex and subsp. ballota [Desf.] Samp.), Quercus faginea Lam. (Portuguese oak), Olea europaea L. var. europaea (cornicabra olive tree), and Juglans regia L. (walnut tree), where Cocoons had survival rates well above their respective controls (see Figure S3). In Jijona, also Quercus ilex and Olea europaea exhibited good results with the Cocoon, exhibiting survival rates close to $100 \%$ in some cases (see Figure S4), but Tetraclinis articulata (Vahl) Masters (Cartagena's cypress) also exhibited good results using both treatments, in which controls reached $86 \%$ survival rates.

\section{2 | Seedling growth}

Seedling growth depended not only on local environmental conditions but also on the species. At the same time, a similar trend toward survival was observed (see Figures S7-S13, Annex 3). A clear tendency toward a better growth of seedlings planted with Cocoon was noted in diameter and height when survival is higher, such as in Quercus ilex and Olea europaea (Figure 3). However, for some species, like Rosmarinus officinalis, there were no significant differences between treatments, and for other species, controls presented higher growth than Cocoons, such as almond trees in Sierra María (Figure 3). Regarding root development, differences were only observed in the cornicabra olive tree (Figure S13, Annex 3). 


\section{CONTROL}

Tifaracás

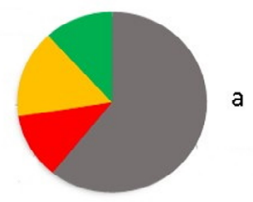

Jijona

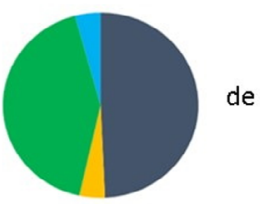

Tous

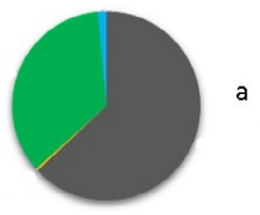

Almería

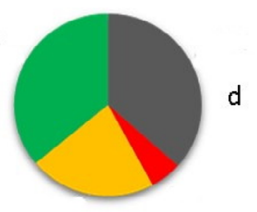

El Bruc

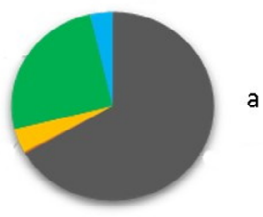

Ptolemais

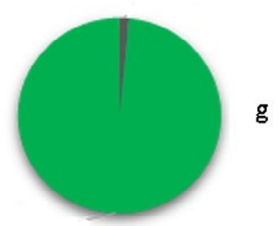

\section{COCOON}
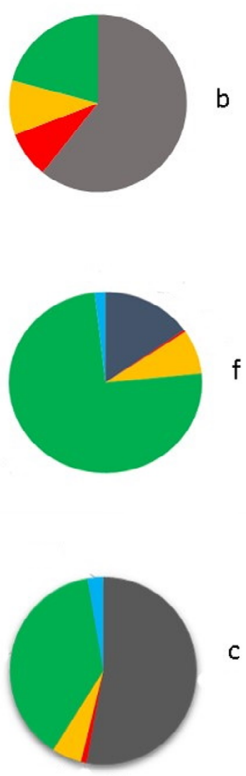

- Dead seedling

- Severely affected seedling

Affected seedling

* Healthy seedling

- Resprouted seedling

FIGURE 2 Physiological state of all seedlings (without discriminating by plant species) after 2 years of planting with cocoon technology and without (control) in each experimental site. Different letters show statistically significant differences $(\alpha=0.05 \%)$ [Colour figure can be viewed at wileyonlinelibrary.com]

\section{3 | Cocoon biodegradation}

Cocoon biodegradation is an important aspect to evaluate, since its design, which foresees using biodegradable material, aims at incorporation into the soil once its watering function is completed. At a general level (Figure 4), the vast majority of Cocoons presented the bowl in functional condition, but with the lid of the device sunk, damaged, or not present (State 1). In a quarter of the installed devices, the
Cocoon began showing signs of biodegradation, such as cracks or holes in its bowl (State 2). There were a lower percentage of completely biodegraded Cocoons (State 4). As observed, some Cocoons in State 1 could retain runoff and rainwater, thereby increasing the water availability for the respective seedlings. In fact, this water retention capacity 2 years after implantation, which is longer than the expected useful life, had been utilized in the new Tifaracás plantings (third and fourth plantings, see Table S1) for refilling the 

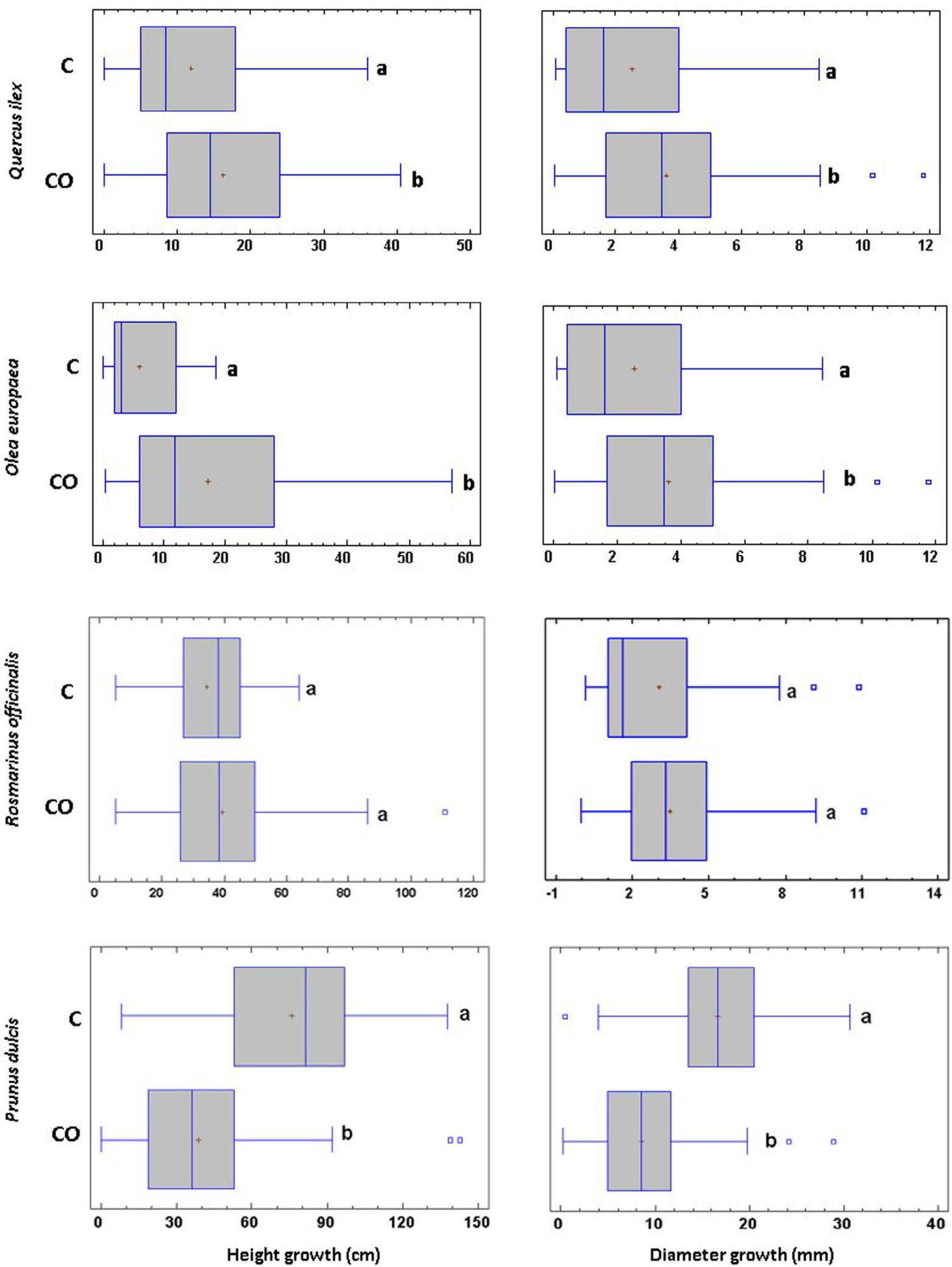

FIGURE 3 Height and diameter growth between 2017 and 2019 of Quercus ilex ssp ilex and Olea europaea var. cornicabra (El Bruc), Rosmarinus officinalis and Prunus dulcis (Sierra María). Different letters show statistically significant differences ( $\alpha=0.05 \%)$. C, control; CO, Cocoon [Colour figure can be viewed at wileyonlinelibrary.com] 

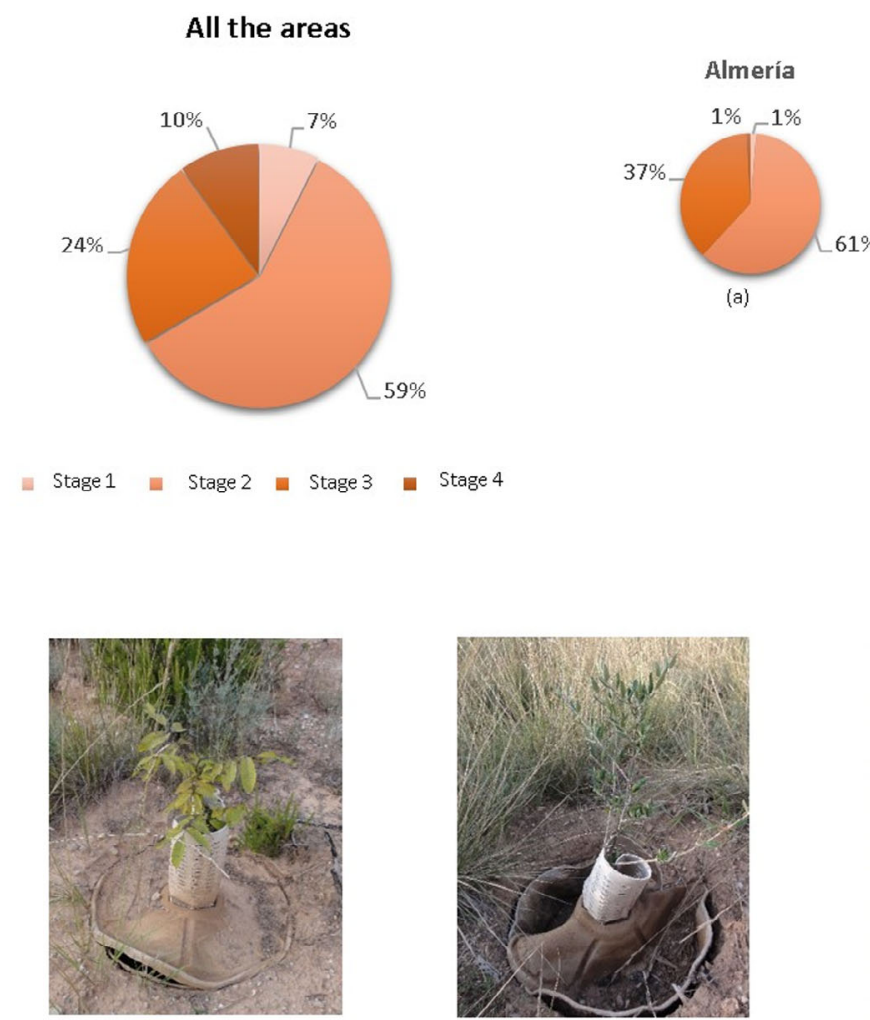

Stage 1

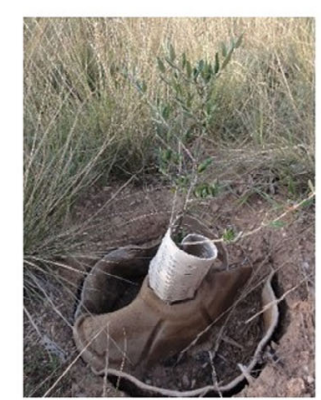

Stage 2

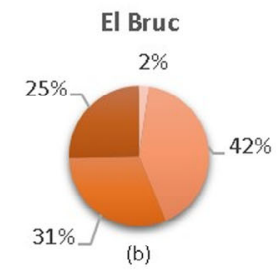

(b)

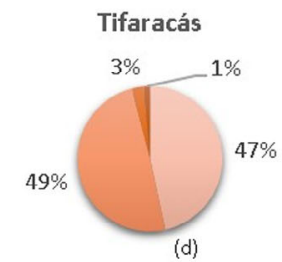

(d)

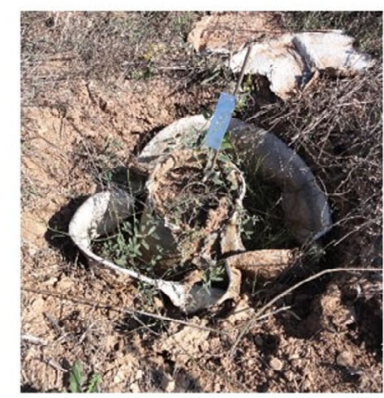

Stage 3

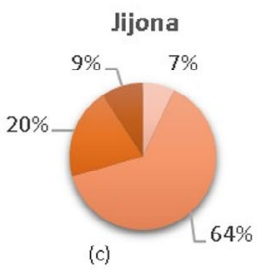

Ptolemais
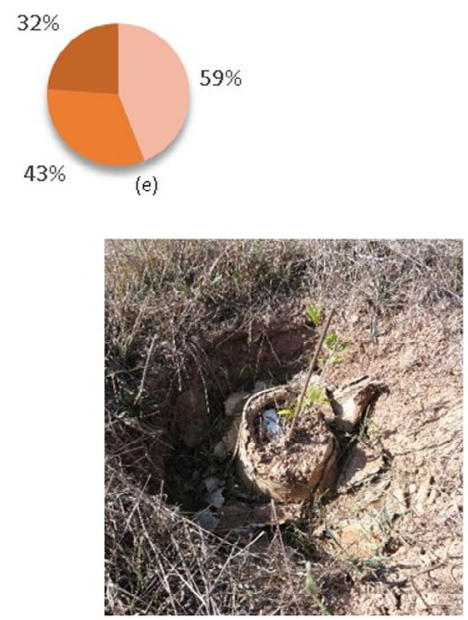

Stage 4

FIGURE 4 Cocoon's degradation State after 2-2.5 years installed at field. Stage 1: Cocoon OK: With or without shelter, but with lid; Stage 2: Lid collapsed but bowl apparently in good state (without cracks, holes); Stage 3: Bowl with signs of degradation (cracks, holes); Stage 4: Highly degraded bowl (almost incorporated into soil) [Colour figure can be viewed at wileyonlinelibrary.com]

bowls during the summer, in which the retained water greatly improved the survival ratios.

These results differed according to the study area (Figure 4). Although State 2 occurred most frequently (except in Calabria), the differences could still be observed locally. The presence of Cocoon residues incorporated into the soil was very scarce or not observed in most areas, except in El Bruc, Calabria, and Jijona. These three zones, together with Sierra María (a large proportion of Cocoons in State 3), were the ones with the greatest global Cocoon biodegradation. The area with the least biodegradation was Tifaracás, with States 1 and 2 occupying $96 \%$ of the Cocoons studied, followed by Tous and Ptolemais (Figure 4).

\subsection{Vegetation structure and diversity}

The structure and floristic biodiversity data are presented in Tables S2 and S3 of Annex 4, respectively. All uncropped areas in the Iberian Peninsula showed a positive trend in view of herbaceous and/or woody vegetation cover and/or floristic composition. However, in Ptolemais and Tifaracás, we could not identify differences in the structure or composition of the vegetation with the 2017 sampling.

The characterization of the natural vegetation in Sierra María was carried out in the temporary dry riverbank (rambla), since the almond plantations are subjected to tillage. Table S2 shows a reduction in the cover and height of woody plants, which were accompanied by an increase in the cover of herbaceous plants. Regarding plant diversity, there was a net change in 12 species (14 new species appeared and 26 were not found). Among these, we noted, on the one hand, the disappearance of abundant species in 2017 such as Hordeum murinum or Tamarix gallica, and on the other, a high frequency in the appearance of Avena fatua and Euphorbia sp. In 2019, the vegetation cover of the dry temporary riverbank upper zone suffered the effects of sporadic torrential rains common in this area, which generated a flood that washed away the vegetation.

In the El Bruc area, there was an increase (2019 vs. 2017 sampling) in both herbaceous and woody covers for the three subzones of sampling, which was accompanied by an increased average height of both types of vegetation (Table S2). This increased plant cover was also accompanied by increased species richness. With respect to the inventories of 2017, in stony and shallow soils, some Asteraceae appeared abundant (Centaurea scabiosa ssp. scabiosa, Helichrysum stoechas, and Scorzonera angustifolia) and grasses, such as Brachypodium phoenicoides, increased in abundance, which eventually became the dominant species in this area. In general, Rosaceae plants (Amelanchier ovalis, Rosa canina, etc.) and Fabaceae also increased. In agricultural soils that are deeper and finer textured, the trend was very similar, but with some differences. In these soils, Asteraceae 
showed a reduced abundance, which became testimonial species, while the Rubiaceae like Galium lucidum and Rubia peregrina appeared. As in the previous area, the Fabaceae, in particular Dorycnium penthaphyllum, presented great abundance, and several species of grasses appeared albeit with low abundance. In addition, Helianthemum syriacum and Rosmarinus officinalis, abundant plants in neighbouring areas, which were absent in 2017, appeared with high frequency in 2019.

In the Jijona and Tous areas, there was also a tendency of increasing vegetation cover of both woody and herbaceous species. Moreover, in Jijona, for woody species, the trend of cover increment was accompanied by an increase in the average height of the plants. However, for the herbaceous species, the average height scarcely increased when compared with 2017. In Tous, there is an increase in both the cover of woody and herbaceous species. However, this gain was not accompanied by an increase in average height, which remained stable. Regarding floristic diversity, both areas remained quite stable between 2017 and 2019.

\section{5 | Plant competition evaluation}

With respect to the data collected from the vegetation surrounding the seedlings in the different study sites (Table 3), we could observe two different tendencies. In some areas of El Bruc and Jijona, we see a pattern of higher biomass weight with greater cover in controls. In the driest areas, such as Tifaracás, or even in areas experiencing similar annual rainfall like Tous, we could see a greater development of vegetation around Cocoons.

\section{4 | DISCUSSION}

Overall, significant differences were found between seedlings planted with Cocoons and controls. Seedling mortality in Cocoons was close to $40 \%$, while in the control group reached $60 \%$. In addition to this moderate improvement in survival, surviving plants had a better physiological state when Cocoon was used. These differences could be attributed to nutrient uptake being highly dependent on water availability in arid and semiarid environments (Maestre et al., 2005; Powers \& Reynolds, 1999). By providing water to the planting sites using the Cocoon device, the plants would be able to overcome or reduce this limitation and make better use of available nutrients, thereby increasing their survival and growth. In fact, the Cocoon not only provides water to the plant during the first months, but it also creates a micro catchment that allows for greater infiltration of rainwater and accumulation of runoff around the plant. Moreover, it not only increases the water supply, but also reduces water losses. The plant protector reduces evapotranspiration, and the lid and the bowl itself reduce competition with herbs, especially during the first year. In addition, the seedlings planted with the Cocoon had a tendency toward a more developed root system than controls did, which resulted in a greater development of the aerial biomass for some species.
Within the wide range of climates tested, the driest one (Tifaracás) was also the most challenging for the Cocoon (unless rewatered), which has a survival rate of below $30 \%$. However, in previous restoration projects carried out in nearby areas with conventional planting systems, the mortality rates were close to $100 \%$ (CREAF, 2017a, 2017b), for which the Cocoon could be considered an interesting alternative for planting in these arid climates. It is especially interesting, in this case, to analyze the balance between the increase in survival due to rewatering and the consequent increase in maintenance costs. Although implementation costs of the Cocoon technology are initially higher than conventional methods, it is nevertheless regarded as a viable option for reducing seedling mortality without increasing maintenance costs in the long run. In the plantings carried out in 2018 and 2019 (see Table S1), the Cocoons were refilled twice during the summer, which improved the survival rate (see Annex 5). Given the results, the option of refilling the Cocoon bowl, despite involving higher initial cost, could be an optimal solution for planting in the drylands of the Canary Islands.

In subhumid regions, like Ptolemais, seedlings planted with Cocoon present similar survival rates as those planted with common techniques. Regarding Cupressus sempervirens, differences in mortality ratios were observed among seedlings having different heights (ages) planted with the Cocoon: $46 \%$ in $50-\mathrm{cm}$ high specimens versus $24 \%$ in $30-\mathrm{cm}$ high specimens. This outcome supports the recommendation that seedlings planted with the Cocoon should preferably be 1 year old, as reported previously (Land Life Company, 2016). Cupressus seedlings are sensitive to extreme weather conditions and adapt better when they are small in size (low height) because they are able to develop stronger root systems quickly. At this site, spring plantings recorded higher survival rates than autumn ones due to better weather conditions for Cupressus implantation.

In contrast, in areas with drier rainfall regimes like Jijona or EI Bruc, the differences between control and Cocoon are significant, as the efficacy of this device is demonstrated in adverse conditions, such as the prolonged drought and high temperatures of Summer 2017. This is especially true in the case of El Bruc, where a $30 \%$ reduction of annual rainfall occurred (449 $\mathrm{mm}$ throughout 2017), especially in the summer (70\% reduction, $58 \mathrm{~mm}$ for the whole season).

Regarding soil conditions, the Cocoons could not be properly installed in shallow and stony soils, like in some parts of the Tous site. Additionally, the strong winds at this site blew out the Cocoon shelters, particularly those that were not properly installed. As a result, the affected seedlings were exposed prematurely to high irradiation and desiccating winds. Therefore, the Cocoon is not recommended for Leptosols or those having a petrocalcic horizon near the surface (IUSS Working Group WRB, 2015), such as those existing in the Sierra María almond fields. Planting under these conditions means that the Cocoons could not perform to their full potential, which renders this technology less competitive compared with usual methods.

Regarding the different plant species, the high mortality in arbequin olive tree plantings in El Bruc (both in control and Cocoons) should be attributed to the bad quality of the seedlings, with rotting roots, stem scars, leaf loss, and chlorosis (CREAF, 2017a, 2017b). In 
TAB LE 3 Herbaceous cover and plant biomass in $1 \mathrm{~m}$ diameter circles around control (C) and Cocoon (CO) seedlings, after 2-2.5 years of planting in four areas

\begin{tabular}{|c|c|c|c|c|c|}
\hline Site & Subsite & Treatment & Herbaceous cover (\%) & Plant biomass ( $\mathrm{g} \mathrm{m}^{-2}$, wet weight) & Plant biomass ( $\mathrm{g} \mathrm{m}^{-2}$, dry weight) \\
\hline Tifaracás & TI1 & C & $70 \pm 35^{a}$ & $77 \pm 41^{\mathrm{a}}$ & $71 \pm 36^{a}$ \\
\hline Tifaracás & TI1 & $\mathrm{CO}$ & $95 \pm 5^{\mathrm{a}}$ & $95 \pm 15^{\mathrm{a}}$ & $89 \pm 14^{a}$ \\
\hline Jijona & J1 & $\mathrm{CO}$ & $12 \pm 2^{\mathrm{a}}$ & $333 \pm 141^{a}$ & $134 \pm 49^{a}$ \\
\hline Jijona & $\mathrm{J} 2$ & C & $52 \pm 11^{\mathrm{a}}$ & $596 \pm 217^{\mathrm{a}}$ & $342 \pm 55^{\mathrm{a}}$ \\
\hline Tous & TO1 & $\mathrm{C}$ & $0 \pm 0^{a}$ & $0 \pm 0^{a}$ & $0 \pm 0^{a}$ \\
\hline Tous & TO1 & $\mathrm{CO}$ & $8 \pm 2^{b}$ & $98 \pm 24^{b}$ & $48 \pm 12^{b}$ \\
\hline Tous & TO2 & C & $3 \pm 1^{\mathrm{a}}$ & $57 \pm 14^{a}$ & $23 \pm 12^{\mathrm{a}}$ \\
\hline Tous & TO2 & $\mathrm{CO}$ & $9 \pm 1^{\mathrm{b}}$ & $189 \pm 26^{b}$ & $98 \pm 12^{b}$ \\
\hline El Bruc & EB1 & C & $47 \pm 3^{a}$ & $178 \pm 85^{a}$ & $76 \pm 36^{a}$ \\
\hline El Bruc & EB3 & C & $53 \pm 22^{\mathrm{a}}$ & $273 \pm 207^{a}$ & $149 \pm 93^{a}$ \\
\hline El Bruc & EB3 & $\mathrm{CO}$ & $31 \pm 7^{a}$ & $258 \pm 118^{a}$ & $133 \pm 62^{a}$ \\
\hline Ptolemais & РT3 & C & $47 \pm 7^{a}$ & $773 \pm 8^{a}$ & $702 \pm 5^{a}$ \\
\hline Ptolemais & РT3 & $\mathrm{CO}$ & $49 \pm 10^{a}$ & $912 \pm 10^{a}$ & $833 \pm 6^{a}$ \\
\hline
\end{tabular}

Note: Values represent mean \pm standard error. Different letters indicate significant differences at $p<0.05$ between $\mathrm{C}$ and CO per subsite and parameter

contrast, arbequin olive trees planted in Jijona had a very high survival rate (almost $90 \%$ ), with approximately $75 \%$ of seedlings planted with Cocoon healthy and growing, probably aided by runoff collection in the Cocoons. In general, the Cocoon yielded very good results in the plantings in Jijona, a site with a semiarid climate ( $<450 \mathrm{~mm}$ per year) and very poor soil with an extremely high carbonate content (77\%).

The response of the holm oak (Quercus ilex) subspecies is especially remarkable. Ballota subspecies performed very well in El Bruc, with a survival rate greater than $60 \%$ and a statistically significant higher growth with the Cocoon. This holm oak subspecies planting could be considered as an example of assisted migration strategy for adapting to climate change (IPCC, 2007; Pramova et al., 2019). This indigenous subspecies of southern Spain and northwestern Africa was planted at higher latitude, which simulates the displacement of the distribution area that this tree could suffer from amidst climate change by applying the assisted migration mechanism (Sansilvestri et al., 2016; Schwartz et al., 2012). Another plant species that responds well to assisted migration is Tetraclinis articulata. This small tree, which is originally an Ibero-African endemism mostly located in northwestern Africa and has only two small natural populations in Europe, namely in Malta and Sierra de Cartagena (SE Spain) (TGM, 2020), was planted in Jijona (outside its distribution area) with very good results.

These assisted migration tests were also performed with typical agricultural tree species. The cornicabra olive tree variety was planted in El Bruc and in Jijona. This variety is typical of central and southern Spain. They are vigorous, erect bearing, and with thick canopy density. It adapts better to continental climates than the arbequin olive trees or the vera variety, the latter being the variety historically used in the area of El Bruc, which we also found in different places in the province of Barcelona and Valencia (Gómez-Escalonilla \& Vidal, 2006). Both in El Bruc and in Jijona, the cornicabra variety responded better than the arbequin variety. The cornicabra variety also adapted better than Vera in El Bruc, with cornicabra seedlings showing higher survival rates and vigor. Since water deficit (moisture stress) is the most persistent environmental stress on fruit crops (Petros et al., 2020), the Cocoon could help in installing crops in arid and semiarid lands.

Based on the data available, there is still insufficient evidence demonstrating that the Cocoon improves the growth of seedlings in comparison to the traditional techniques. Regarding growth in length and weight of the roots, significant differences were found only for cornicabra olive trees in El Bruc, which were higher in the plants with Cocoon. However, as the available data only reflect plant growth in 2 years (2017-2019) in view of the slow evolution of vegetation in drylands (Yu \& Wang, 2018), it is possible to state that the positive trends observed in many cases suggest that if the growth monitoring were repeated after some years, these differences could increase (Shackelford et al., 2018).

The structure and biodiversity of the accompanying vegetation showed different trends for the studied areas, in terms of climatic and biotic factors, including anthropogenic ones. Generally, in the nonextreme Mediterranean climate sites tested, an increase in vegetation growth and/or plant diversity had been observed. According to the intermediate disturbance hypothesis (Connell, 1978), the increase in biodiversity of these communities is an indicator that they are growing in complexity and maturity, as they have not reached the 
intermediate degree of disturbance (or recovery), where maximum floristic richness would be produced. However, the elapsed time can be considered rather short for proper assessment of improvements in biodiversity.

The Tifaracás and Sierra María sites remained stable without appreciable changes in plant biodiversity. This slow evolution could be due to the hard environmental conditions in these areas. The restoration of degraded drylands has several limitations: (1) resource (water nutrients, soil organic matter, propagules) levels are uniformly low; (2) harsh microenvironmental conditions limit seedling recruitment; and (3) animals have a greater potential for disrupting restoration efforts in arid systems (Roundy et al., 1995). The effect of animals impeding restoration dynamics could be clearly observed in Tifaracás, where there is a large population of wild goats. Moreover, extreme events are also a limitation in arid land restoration (Olsson et al., 2019). The slight changes observed in Sierra María, with a reduction of woody plants, are probably due to the 2018 flood that affected the restored area.

Cocoon biodegradation is also affected by rainfall regime, increasing in areas with higher rainfall values. As the lid is usually the most exposed part of this device, it is easily susceptible to damages. Since Cocoon biodegradation is slower in dry conditions, trees growing under such conditions can also benefit longer from extended, and still needed Cocoon support: more water available by Cocoon refilling after rain events, reduced evaporation losses, and were resilient to competing for adjacent weeds. As mentioned above, this fact became advantageous for the planting carried out in Tifaracás in 2018, where Cocoons were refilled to increase their survival, being an experience with very good results. Moreover, partially biodegraded Cocoons may still provide rainwater and be a shield against evaporation, implying an extended water availability to support tree growth.

As a conclusion, the Cocoon technology proved useful for reforestation in drylands. In general, conventional plantations showed higher mortalities and relatively lower vigour rates than planting sites using this ecotechnology. The direct and indirect water supply, the mitigation of plant competition around the seedling, the reduction of evapotranspiration, and the microcatchment effect, create a suitable set of conditions for improving the physiological state of plants, which increases their survival. However, a case-per-case evaluation is needed before deciding on this technology. Cocoons have an added advantage when planting site conditions impose more drought stress (lower rainfall, sandy textured soils with poor water retention), and/or when tree species used are less adapted to drought stress in the early stages of development. However, Cocoons are less competitive than common techniques for planting in soils with high water retention capacity, or in Mediterranean humid climates, or for planting droughttolerant species. Small differences in survival and growth, combined with higher costs of planting with Cocoons, make this ecotechnology less interesting in these situations.

\section{ACKNOWLEDGMENTS}

This study has been funded by the projects LIFE The Green Link (Restore desertified areas with an innovative tree growing method across the Mediterranean border to increase resilience; LIFE15 CCA/ES/000125) and LIFE Nieblas (Reforestation \& Climate Change Mitigation: tests, evaluation and transfer of innovative methods based on fog collection; LIFE19 CCM/ES/001199), co-funded by the EU LIFE program. The authors would like to express their gratitude to the reviewers for their efforts in strengthening the quality of this paper.

\section{DATA AVAILABILITY STATEMENT}

The data that supports the findings of this study are available in the supplementary material of this article.

\section{ORCID}

Vicenç Carabassa (ID) https://orcid.org/0000-0002-8728-2818 Julián Campo (D) https://orcid.org/0000-0003-0009-138X

\section{REFERENCES}

Alday, J. G., Zaldívar, P., Torroba-Balmori, P., Fernández-Santos, B., \& Martínez-Ruiz, C. (2016). Natural forest expansion on reclaimed coal mines in Northern Spain: The role of native shrubs as suitable microsites. Environmental Science and Pollution Research, 23, 13606-13616. https://doi.org/10.1007/s11356-015-5681-2

Campo, J., Andreu, V., Gimeno-García, E., González, O., \& Rubio, J. L. (2006). Occurrence of soil erosion after repeated experimental fires in a Mediterranean environment. Geomorphology, 82(3-4), 376-387. https://doi.org/10.1016/j.geomorph.2006.05.014

Campo, J., Gimeno-Garcia, E., Andreu, V., Gonzalez-Pelayo, O., \& Rubio, J. L. (2008). Aggregation of under canopy and bare soils in a Mediterranean environment affected by different fire intensities. Catena, 74(3), 212-218. https://doi.org/10.1016/j.catena.2008. 05.002

Carabassa, V., Ortiz, O., \& Alcañiz, J. M. (2019). RESTOQUARRY: Indicators for self-evaluation of ecological restoration in open-pit mines. Ecological Indicators, 102, 437-445. https://doi.org/10.1016/j.ecolind. 2019.03.001

Cohen-Shacham, E., Walters, G., Janzen, C., \& Maginnis, S. (Eds.). (2016). Nature-based solutions to address global societal challenges (p. 97). Gland: IUCN.

Connell, J. H. (1978). Diversity in tropical rain forest and coral reefs. Science, 199, 1302-1310.

CREAF. (2017a). Baseline characterisation report. Centre de Recerca Ecològica i Aplicacions Forestals. https://thegreenlink.eu/wp-content/ uploads/2017/01/Deliverables-A1-Baseline-report.pdf

CREAF.(2017b). Above ground, below ground and carbon stock monitoring protocol. Centre de Recerca Ecològica i Aplicacions Forestals. https:// thegreenlink.eu/wp-content/uploads/2017/05/A.2.-Del_Trainingcourse-material.pdf

Díaz-Hernández, J. L., Barahona, E., \& Linares, J. (2003). Organic and inorganic carbon in soils of semiarid regions: A case study from the Guadix-Baza basin (Southeast Spain). Geoderma, 114, 65-80. https:// doi.org/10.1016/S0016-7061(02)00342-7

Gómez-Escalonilla, M., \& Vidal, J. (2006). Variedades del olivar. Madrid: Ministerio de Agricultura, Pesca y Alimentación.

IPCC (2007). Climate change 2007: Impacts, adaptation and vulnerability. Contribution of Working Group II to the Fourth Assessment Report of the Intergovernmental Panel on Climate Change. Cambridge, UK: Cambridge University Press, p. 976. https://www.ipcc.ch/site/assets/ uploads/2018/03/ar4_wg2_full_report.pdf

IUSS Working Group WRB (2015). World Reference Base for Soil Resources 2014, update 2015. International soil classification system for naming soils and creating legends for soil maps (World Soil Resources Reports No. 106). Rome: FAO. 
Land Life Company. (2016). Cocoon planting instructions. Amsterdam: LLC.

Land Life Company. (2021, May 28). Projects. https://landlifecompany. com/projects

López-Marcos, D., Turrión, M. B., \& Martínez-Ruiz, C. (2020). Linking soil variability with plant community composition along a mine-slope topographic gradient: Implications for restoration. Ambio, 49, 337-349. https://doi.org/10.1007/s13280-019-01193-y

Maestre, F. T., Valladares, F., \& Reynolds, J. F. (2005). Is the change of plant-plant interactions with abiotic stress predictable? A metaanalysis of field results in arid environments. Journal of Ecology, 93, 748-757. https://doi.org/10.1111/j.1365-2745.2005.01017.xMAP

MAPA (2019). La desertificación en España. Madrid, SP: Ministerio de agricultura, pesca y alimentación. https://www.mapa.gob.es/es/desar rollo-rural/temas/politica-forestal/desertificacion-restauracion-forest al/lucha-contra-la-desertificacion/lch_espana.aspx.

MEA. (2005). Ecosistemas y bienestar humano: Síntesis sobre Desertificación. Washington, DC: World Resources Institute.

Mohsin, F., Arias, M., Albrecht, C., Wahl, K., Fierro-Cabo, A., \& Christoffersen, B. (2021). Species-specific responses to restoration interventions in a Tamaulipan thornforest. Forest Ecology and Management, 491, 119154. https://doi.org/10.1016/j.foreco.2021.119154

Muñoz-Rojas, M., Hueso-Gonzalez, P., Branquinho, C., \& Baumgartl, T. (2021). Restoration and rehabilitation of degraded land in arid and semiarid environments: Editorial. Land Degradation \& Development, 32, 3-6. https://doi.org/10.1002/ldr.3640

Olsson, L., Barbosa, H., Bhadwal, S., Cowie, A., Delusca, K., FloresRenteria, D., Hermans, K., Jobbagy, E., Kurz, W., Li, D., Sonwa, D. J., \& Stringer, L. (2019). Land degradation. In Climate change and land: An IPCC special report on climate change, desertification, land degradation, sustainable land management, food security, and greenhouse gas fluxes in terrestrial ecosystems. IPCC. http: ipcc.ch/srccl/

Petros, W., Tesfahunegn, G. B., Berihu, M., \& Meinderts, J. (2020). Watersaving techniques on growth performance of Mango (Mangifera indica L.) Seedlings in Mihitsab-Azmati Watershed, Rama Area, Northern Ethiopia. Agricultural Water Management, 243, 106476. https://doi. org/10.1016/j.agwat.2020.106476

Powers, R. F., \& Reynolds, P. E. (1999). Ten year responses of ponderosa pine plantations to repeated vegetation and nutrient control along an environmental gradient. Canadian Journal of Forest Research, 29, 1027-1038. https://doi.org/10.1139/x99-104

Pramova, E., Locatelli, B., Djoudi, H., Lavorel, S., Colloff, M., \& Martius, C. (2019). Para adaptar la restauración de la tierra a un clima cambiante: Aceptemos lo que sabemos y lo que no. CIFOR. https://doi.org/10. 17528/cifor/007462

Roundy, B. A., McArthur, E. D., Haley, J. S. \& Mann, D. K. comps. (1995). Proceedings: Wildland shrub and arid land restoration symposium; 1993 October 19-21; Las Vegas, NV. Gen. Tech. Rep. INT-GTR-315. US Department of Agriculture, Forest Service, Intermountain Research Station.
Salem, B. B. (1989). Arid zone forestry: A guide for field technicians. Rome: Publications Division, Food and Agriculture Organization of the United Nations.

Sansilvestri, R., Frascaria-Lacoste, N., \& Fernández-Manjarrés, J. (2016). One option, two countries, several strategies: Subjacent mechanisms of assisted migration implementation in Canada and France. Restoration Ecology, 24(4), 489-498. https://doi.org/10.1111/rec.12343

Schwartz, M. W., Jessica, J., Jason, M. M., Sax, D. F., Borevitz, J., Brennan, J., Camacho, A. E., Ceballos, G., Clark, J. R., Doremus, H., Early, R., Etterson, J. R., Fielder, D., Gill, J. L., Gonzalez, P., Green, N., Hannah, L., Jamieson, D. W., Javeline, D., ... Zellmer, S. (2012). Managed relocation: Integrating the scientific, regulatory, and ethical challenges. Bioscience, 62, 732-743. http://dx.doi.org/10.1525/bio.2012.62.8.6

Shackelford, N., Miller, B. P., \& Erickson, T. E. (2018). Restoration of opencut mining in semiarid systems: A synthesis of long-term monitoring data and implications for management. Land Degradation \& Development, 29, 994-1004. https://doi.org/10.1002/ldr.2746

TGM. (2020). The Gymnosperm Database. https://www.conifers.org/cu/ Tetraclinis.php

Valdecantos, A., Fuentes, D., Smanis, A., Llovet, J., Morcillo, L., \& Bautista, S. (2014). Effectiveness of low-cost planting techniques for improving water availability to Olea europaea seedlings in degraded drylands. Restoration Ecology, 22(3), 327-335. https://doi.org/10.1111/rec.12076

VOLTERRA. (2021, May 28). Life The Green Link. Áreas del proyecto. https://thegreenlink.eu/es/areas-del-proyecto/

WWF. (2016). Recuperando paisajes: Un nuevo camino para la restauración ecológica. WWF. http://awsassets.wwf.es/downloads/informe_restau racion_ecologica_wwf_2016.pdf

Yu, K., \& Wang, G. (2018). Long-term impacts of shrub plantations in a desert-oasis ecotone: Accumulation of soil nutrients, salinity, and development of herbaceous layer. Land Degradation \& Development, 29, 2681-2693. https://doi.org/10.1002/ldr.300

\section{SUPPORTING INFORMATION}

Additional supporting information may be found in the online version of the article at the publisher's website.

How to cite this article: Carabassa, V., Alba-Patiño, D., García, S., Campo, J., Lovenstein, H., Van Leijen, G., Castro, A. J., González, F., Viera, G., Kourkoumpas, D.-S., Zioga, A. A., Papadelis, C. E., Andreu, V., Gimeno, E., Kallen, S., \& Alcañiz, J. M. (2022). Water-saving techniques for restoring desertified lands: Some lessons from the field. Land Degradation \& Development, 33(1), 133-144. https://doi.org/10.1002/ Idr.4134 